\title{
6. ANALYSIS OF SEDIMENTARY FACIES AND CLAY MINERALOGY OF THE NEOGENE-QUATERNARY SEDIMENTS IN ODP SITE 646, LABRADOR SEA ${ }^{1}$
}

\author{
Michel Cremer, ${ }^{2}$ Noëlle Maillet, ${ }^{2}$ and Claude Latouche ${ }^{2}$
}

\begin{abstract}
The grain-size study and analyses of bulk sediment and clay mineral composition of samples collected from the dominant lithologies recovered at ODP Site 646, located on the northern flank of the Eirik Ridge (Labrador Sea), show variations indicating that contour-following currents, linked to Norwegian Sea Overflow Water (NSOW), have controlled sedimentation since the early Pliocene. These currents were influential until the early Pleistocene, despite the onset of major ice-rafting at about 2.5 Ma. A major mineralogical change occurred during the late Miocene: a decrease in the smectite to illite and chlorite ratio and a decrease of the crystallinity of smectites. This change indicates a renewing of the source rocks, which could result from an important hydrological change at this time. This change also is depicted by grain-size data that suggest the bottom current influence should be set earlier than the Pliocene.
\end{abstract}

\section{INTRODUCTION}

Site 646 , drilled during Leg 105 , is located in the northeastern Labrador Sea on the northwestern flank of the Eirik Ridge (Fig. 1), a sedimentary ridge that was molded by the contour current linked to the Norwegian Sea Overflow Water (Jones et al., 1970). Shipboard observations revealed that the $767-\mathrm{m}$-thick, cored, upper Miocene to Holocene section (Fig. 2) consists mainly of silty and clayey sediments having a relatively low biogenic content. The sediments are commonly structureless and show only a few sedimentary structures, although there is seismic evidence of bottom current-controlled sedimentation. Dropstones were observed in upper Pliocene to Holocene sediments.

Using grain-size analysis of samples collected from the dominant lithologies of sediments at Site 646, this study defines their texture and studies their mineralogy. This study also looks for variations in the sediment sources and their modes of deposition.

\section{METHODS OF STUDY}

We examined 54 samples (each $20 \mathrm{~cm}^{3}$ ) collected from the cored section representing each dominant lithology recovered at Site 646. Samples were taken at about 10 -m intervals (one per core) to investigate vertical variation of texture and mineralogic composition. Additional grainsize data come from more closely spaced samples, collected mainly from lithologic Unit I, to characterize minor lithologies.

\section{Grain Size}

Because the biogenic fraction is usually low and because detrital carbonate is present in this section, we determined grain sizes in bulk samples. Samples were washed through a $63-\mu \mathrm{m}$ sieve. The grain-size distribution of the $<63-\mu \mathrm{m}$ fraction was determined by using a Sedigraph $5000 \mathrm{D}$ particle size analyzer. The sand-sized fraction was observed under the binocular microscope. The fifth coarser percentile and the median diameter were defined. The standard deviation and the skewness were computed using the moment method to characterize grain-size distribution of the total sample (Friedman, 1967; Rivière, 1977).

\section{Mineralogy}

X-ray diffractometry (Philips diffractometer) was used for mineralogical analyses of total sediment and $<2 \mu \mathrm{m}$ fractions using nickel-filtered copper $\mathrm{K} \alpha$ radiation at $25 \mathrm{kV}$ and $20 \mathrm{~mA}$.

\footnotetext{
${ }^{1}$ Srivastava, S. P., Arthur, M., Clement, B., et al., 1989. Proc. ODP, Sci. Results, 105: College Station, TX (Ocean Drilling Program).

2 Département de Géologie et Océanographie, Laboratoire Associé CNRS 197, Université de Bordeaux I, Avenue des Facultés, 33405 Talence Cedex, France.
}

Total sediments. Total sediments were dried, crushed, powdered on a support, and then X-rayed. Minerals were identified according to the characteristic peaks (Torre de Assunçao and Garrido, 1953; Brindley and Brown, 1980); quartz at $3.35 \AA$; calcosodic feldspar between 3.20 and $3.15 \AA$; alkali feldspar between 3.29 and $3.20 \AA$; calcite at $3.03 \AA$; and dolomite at $2.98 \AA$.

The peak height of each mineral was transcribed on a standard curve, and relative mineral abundance was evaluated. Calibration was based on four synthetic reference standards, made up of variable weight mixtures of quartz, feldspar, calcite, and dolomite. Clay quantity, occurrence of heavy minerals, and content of amorphous components were not taken into consideration.

Clay fractions $(<2 \mu \mathrm{m})$. Total sediments were dispersed in deionized water using a mechanical agitator. Samples with high carbonate contents were first treated with $\mathrm{N} / 10 \mathrm{HCl}$. After several washings $(2-3$ times) in deionized water, $<2 \mu \mathrm{m}$ subfractions were separated by gravity settling. After the $<2 \mu \mathrm{m}$ portion of the suspension was centrifuged, the resulting paste was spread on three slides: one was scanned untreated, one was saturated with ethylene glycol, and the third was heated at $550^{\circ} \mathrm{C}$ for $1 \mathrm{hr}$.

Minerals were identified on the basis of their typical reactions to classical treatment (saturation and heat) (Brown, 1961; Thorez, 1975). Abundances of different minerals were estimated from the glycolated samples. The heights of the 001 peaks on the X-ray diagram were used to determine smectite $(17 \AA)$, illite $(10 \AA)$, and kaolinite and chlorite (7.1 \&). Chlorite was distinguished from kaolinite on the basis of the difference between their reflections: 002 for kaolinite $(3.57 \AA)$ and 004 for chlorite $(3.55 \AA)$. Results are given in percentage values; these percentages were evaluated only with regard to the crystallized clay minerals in the $<2 \mu \mathrm{m}$ fraction. Several minerals, such as amphibole, feldspar, and quartz, were observed in this fraction. The amphibole group was identified at 8.30-8.40 $\AA$. Within the fine-grained fraction, quartz was identified at $4.24 \AA$. The $3.35-\AA$ peak, usually used to determine quartz, overlapped the illite 003 peak; feldspar was identified between 3.15 and $3.28 \AA$. All mineralogical analyses were performed under the same operating conditions.

The crystallinity index of illite was estimated according to the width of the $10-\AA$ reflection above the background at one-half the height of the reflection (Dunoyer de Segonzac, 1969). The smectite crystallinity was established using Biscaye's parameter (1965), which measures both the height of the $17-\AA$ reflection above the background (the value is indicated by $p=$ peak) and the depth of the valley $(v)$; the latter is more or less well-developed on the low angle side of the $17-\AA$ reflection.

Because crystallinity of smectites indicated few variations at the site using Biscaye's index, we chose to measure the resolution of the 17- $\AA$ reflection of the glycolated material, i.e., the width at one-half the height of the $17-\AA$ reflection divided by the total height of the same reflection.

The illites, whether ferriferous or aluminous, were characterized with respect to the criteria proposed by Grim et al. (1951), Klingebiel and Latouche (1962), and Esquevin (1969). These authors showed that mica- 


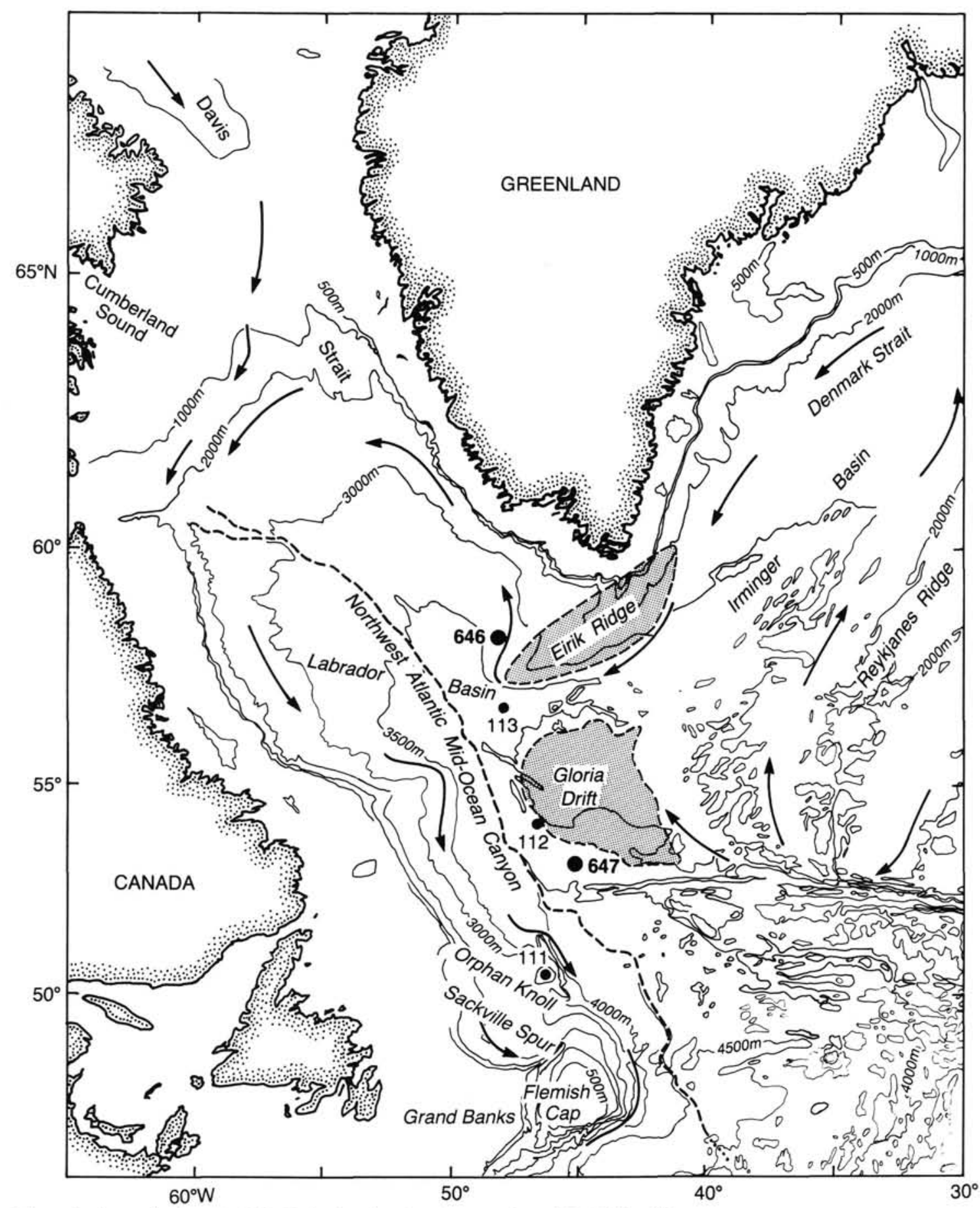

Figure 1. Generalized map of the Labrador Sea showing location of ODP Site 646.

ceous clay minerals of ferriferous and aluminous type exhibit distinct peaks on X-ray diagrams. Index $A(A=$ height of the 001 peak/height of the 002 peak), put forward by Klingebiel and Latouche (1962), takes into account the above characteristics. If $A>3$, micaceous clay minerals are ferriferous, if $A<3$, they are aluminous.

\section{LITHOLOGIC AND SEISMIC UNITS}

Lithologic Unit I (0-236 meters below seafloor [mbsf]), late Pliocene to Holocene, is characterized by the presence of finegrained sediments of sands, granules, and cobbles, mainly of volcanic rock origin, which are scattered or concentrated in dif- fuse layers (Shipboard Scientific Party, 1987). The base of lithologic Unit $\mathrm{I}$ is defined by the disappearance of this material. Dominant lithologies of Subunit IA (0-188 mbsf) are silty clays and clays with variable amounts of carbonate (up to $40 \%$ ) and siliceous $(<10 \%)$ skeletons. These sediments are commonly structureless, except for color bandings or mottles caused by bioturbation.

Minor lithologies are (1) silty and clayey muds characterized by a low biogenic content and a higher proportion of outsized grains or mud clasts, silt, and sand pockets; (2) layers consisting of about $50 \%$ detrital carbonates, from 2 to $50 \mathrm{~cm}$ thick, either 


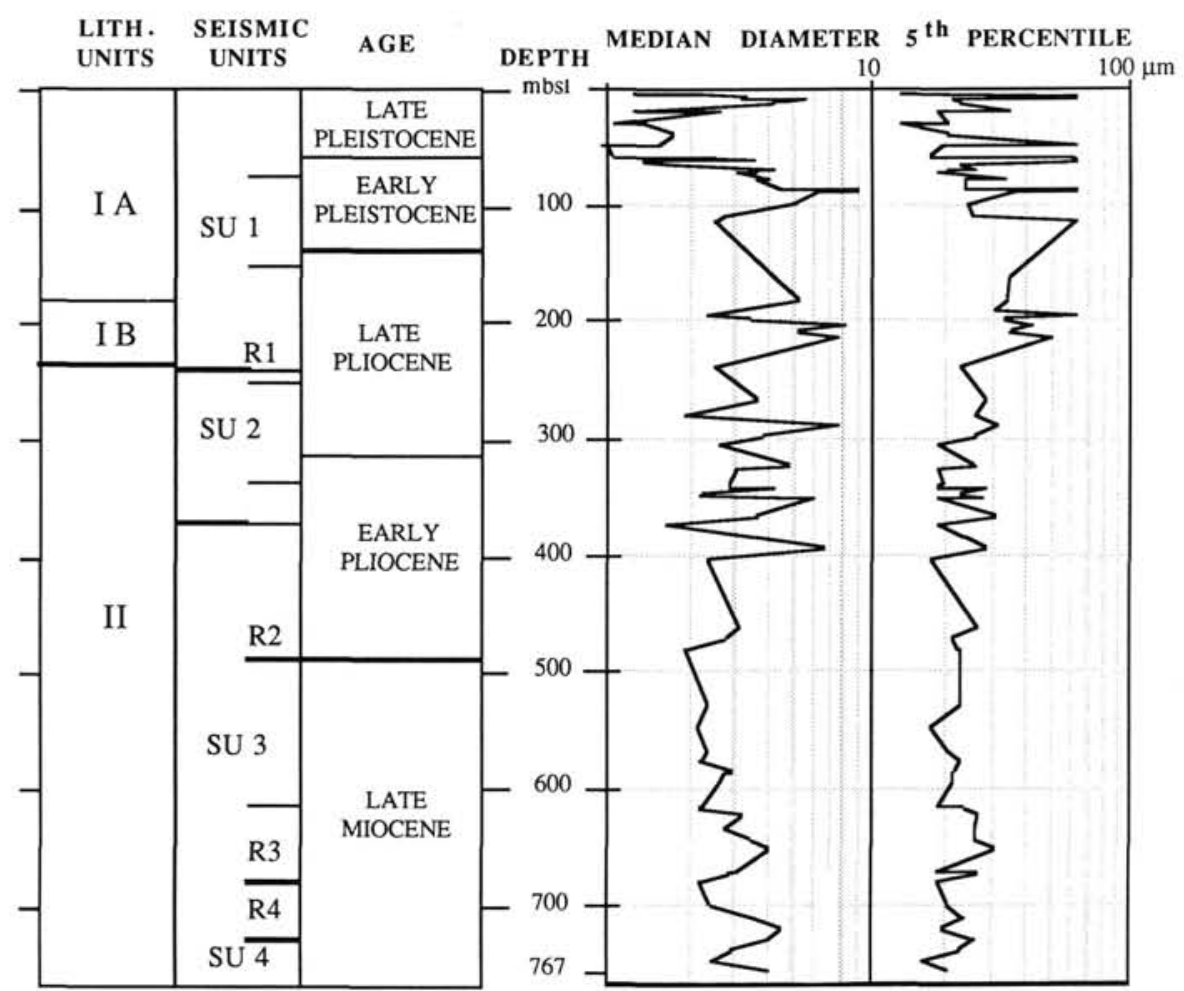

Figure 2. Lithostratigraphic summary for Site 646 showing lithologic units, seismic units, age, median diameter, and fifth coarser percentile.

massive and bioturbated or finely laminated; and (3) finely laminated siliceous silt and clayey silt beds, 1 to $5 \mathrm{~cm}$ thick and containing up to $10 \%$ of heavy minerals. These lithologies repeat themselves in a fine scale (decimetric to metric) of cyclicity that can be seen particularly by variation in biogenic carbonate. Subunit IB (188-236 mbsf) is characterized by a higher content of coarse particles. It contains silty muds and poorly sorted muddy sands that are vaguely color-banded and crudely stratified. Detrital carbonate beds were not observed in this subunit.

Lithologic Unit II (236-767 mbsf), late Miocene to late Pliocene, is dominated by clay-rich sediments: silty clays, clayey silts, clays that contain a higher proportion of nannofossils, up to $30 \%$, between 310 and 470 mbsf. Except for the laminated silt beds that occur above 395 mbsf, the sediments are bioturbated and show little variation in either texture or sedimentary structure.

The base of lithologic Unit I corresponds to a major inconformity, (reflector Rl) at the top of seismic Unit 2 (Fig. 3) This seismic unit is lenticular in shape and shows migrating sediment waves that define a sedimentary ridge molded by bottom currents. The overlying seismic Unit 1 is depicted by continuous reflectors that are more parallel. Below $75 \mathrm{mbsf}$, the latter tends to drape the ridge topography, but with a northward shift of the topographic high; while above $75 \mathrm{mbsf}$, it includes reflectors of higher amplitude and thickens on both sides of this topographic high. Lithologic Unit II includes three distinct seismic units. Seismic Units 3 and 4 contain less continuous and lower-amplitude reflectors, except the regional reflector R2 (490 mbsf) and the R3/R4 doublet $(680,730 \mathrm{mbsf})$ at the top of seismic Unit 4 .

\section{GRAIN-SIZE DISTRIBUTION}

Grain-size analyses of the samples collected from the dominant lithologies, which exclude the laminated detrital carbonate or siliceous silt layers, confirm that the sediments at Site 646 are fine-grained. The median diameter (Fig. 2) rarely exceeds $5 \mu \mathrm{m}$.
A sand content of more than $10 \%$, which warrants the term mud from the sediment classifications used during Leg 105, is only found in samples of lithologic Unit I (Fig. 4). However, the boundary between lithologic Units I and II is marked by an increase of the $>63-\mu \mathrm{m}$ fraction. This includes some outsized detrital grains in lithologic Unit I, but only biogenic skeletons or pyritic concretions in lithologic Unit II, within which it is strictly less than $1 \%$. Siliceous skeletons make up less than $10 \%$ and disappear below $330 \mathrm{mbsf}$. The carbonate content (see mineralogical data) is lower than $20 \%$, except for two samples. Therefore, the nonbiogenic sediment classification will be used here. Using a silt-clay limit at $2 \mu \mathrm{m}$, most of the sediments can be described as clayey silts; only the finer-grained sediments above 70 mbsf are silty clays or muddy clays. The grain-size distributions of the studied samples (Fig. 5) show little variations around moderatly sorted sediments depicted by a symmetrical logarithmic grain-size curve (Rivière, 1977). Apparently, as the median diameter increases, the curves tend toward a parabolic shape characterized by a more distinct fine tail and a positive skewness. In contrast, more hyperbolic-shaped and negatively skewed curves characterize finest-grained sediments, even if they contain sand-sized material. Although grain-size changes may be higher from sample to sample than between the lithologic units, each lithologic unit is characterized by distinct textural trends.

\section{Lithologic Unit I}

Lithologic Unit I contains both the finer- and coarser-grained sediments of the cored section. The $>63-\mu \mathrm{m}$ fraction varies independently of the lower grain-size classes (Fig. 4), but is commonly higher when the whole sediment is finer-grained. In contrast, high coarse silt contents correspond to low sand contents. Therefore, the samples from lithologic Unit I are scattered in the fifth coarser percentile-median diagram (Passega, 1957), where three end-members can be defined (Fig. 6), as follows. 


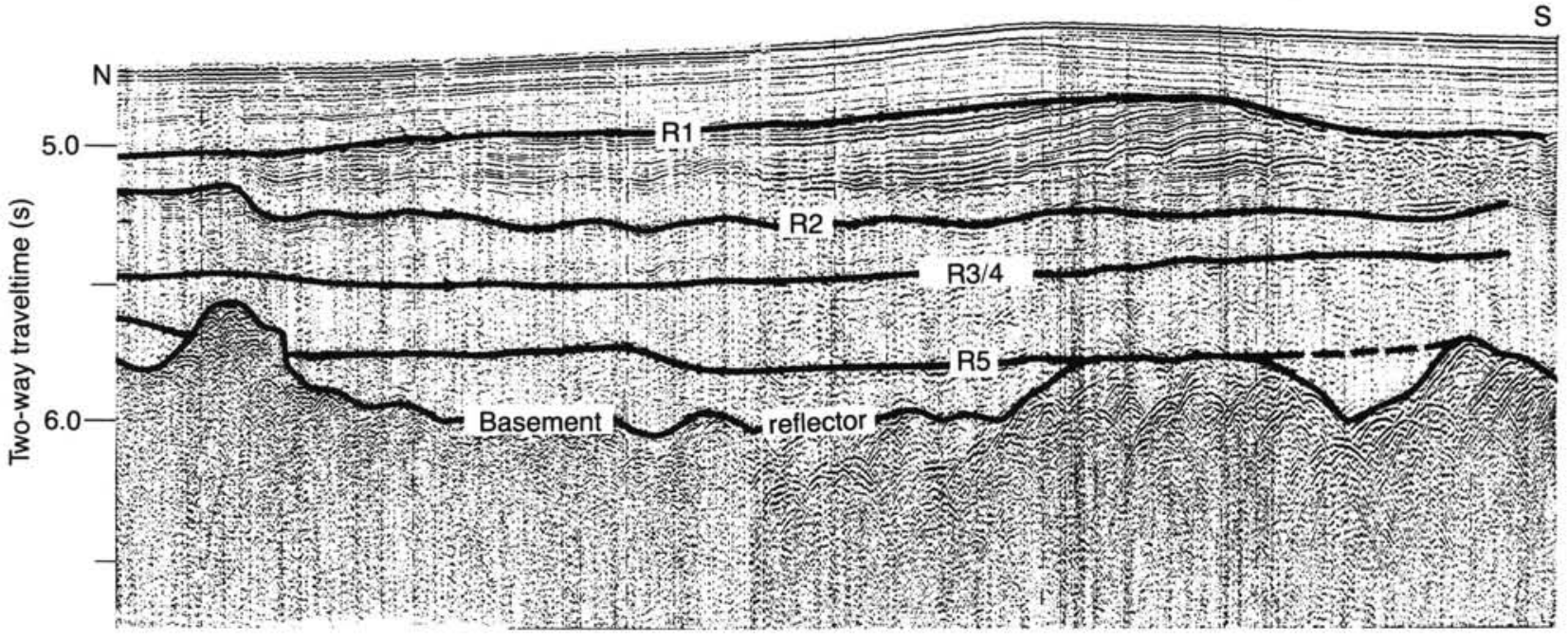

Figure 3. Seismic line (Hudson line 14) across Site 645 showing the major reflectors R1, R2, and R3/4. See Figure 2 for correlations to age, seismic, and lithologic units.

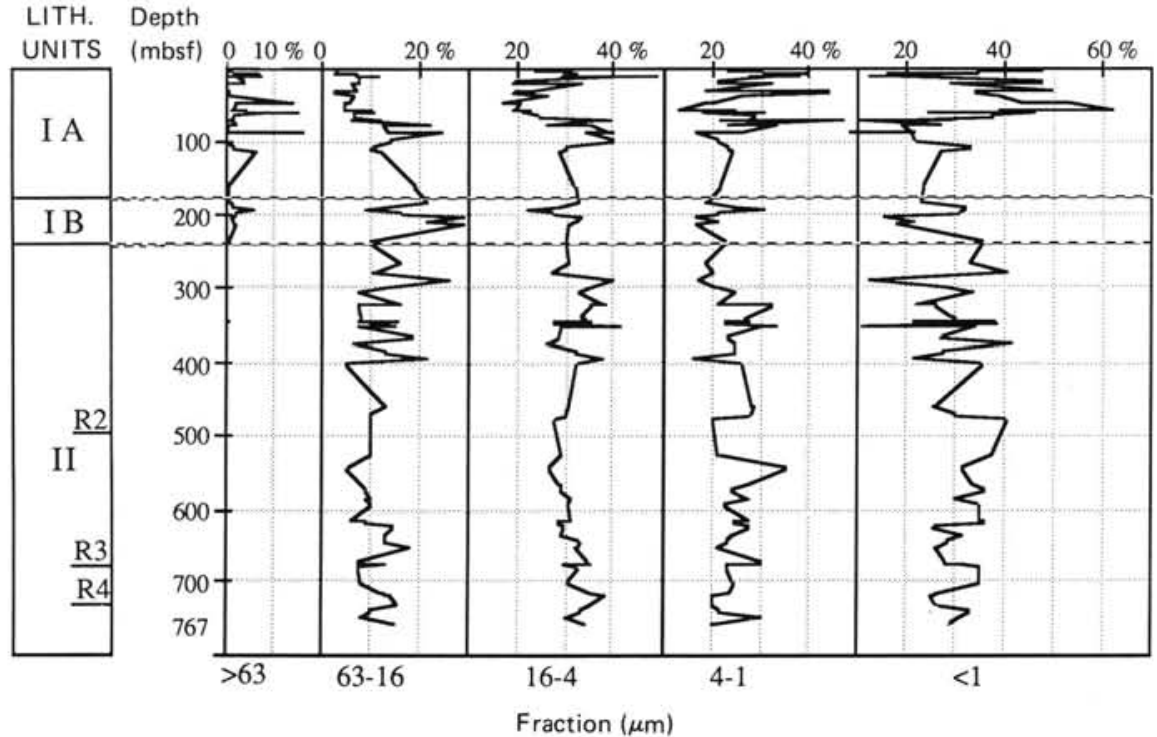

Figure 4. Vertical variation of the sand-, silt-, and clay-sized fractions at Site 646.

1. The very fine-grained sediments (median diameter $<2$ $\mu \mathrm{m}$ ), with very low sand-sized particle content (or a low fifth coarser percentile) are characterized by hyperbolic grain-size curves and a negative skewness (Fig. 5A); they correspond to silty clays with relatively high biogenic content and thus are related to deposition of hemipelagic suspensions.

2. The fine-grained sediments that correspond to poorly sorted clayey muds differ from the former by lower or lack of biogenic contents but mainly by an abnormally high (with respect to low values of the median diameter) fifth coarser percentile that resulted from a notable coarse particle content ranging from fine sand to granule-sized grains. Thus, these are related to deposition of terrigenous uniform suspensions, which include coarse material from iceberg meltout.

3. The coarser-grained sediments (median diameter $>4 \mu \mathrm{m}$ ) correspond to clayey silts that contain no or a very low sandsized fraction and commonly few biogenic skeletons. Their fifth coarser percentile increases with the median diameter. These sediments are moderately to well sorted and characterized by logarithmic to parabolic and positively skewed grain-size curves. These grain-size characteristics indicate deposition from graded suspensions under a current influence.

The distinction between these three types of sediment, with distinct depositional processes, is confirmed by the study of sedimentary structures and grain-size distribution (Fig. 6) in selected samples that are representative of particular structures (Cremer, this volume). The clayey silts show a grain-size distribution near that of the thinly laminated siliceous silt beds that were related to typical silty contourites (Fig. 7), according to the absence of a consistent sequence of structure, their higher heavy mineral content, and associated bioturbations. In contrast, the biogenic, skeleton-bearing, silty clays, which are structureless and bioturbated throughout, are related to hemipelagites depos- 

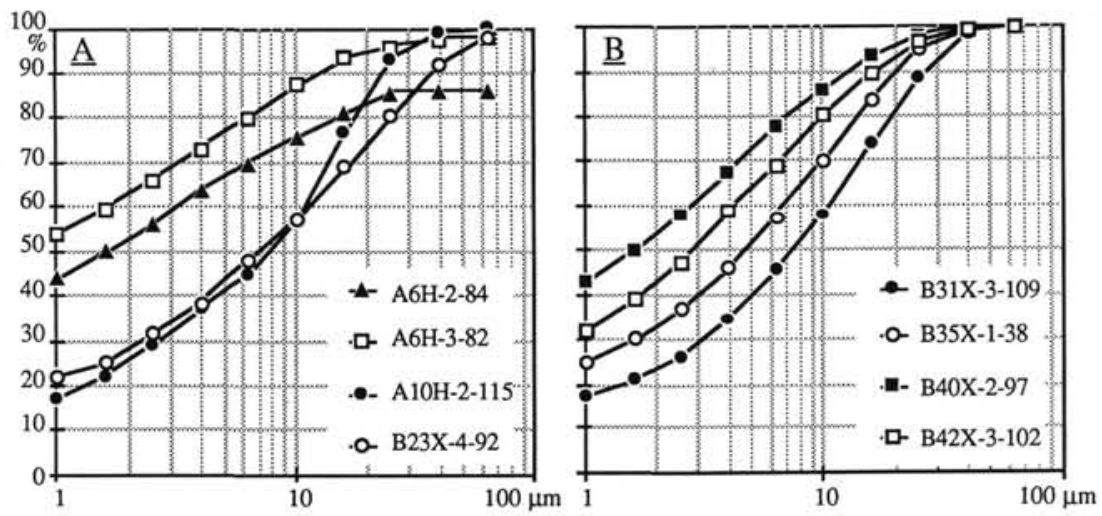

Figure 5. Cumulative grain-size curves of some typical samples from Site 646. A. Lithologic Unit I. B. Lithologic Unit II.

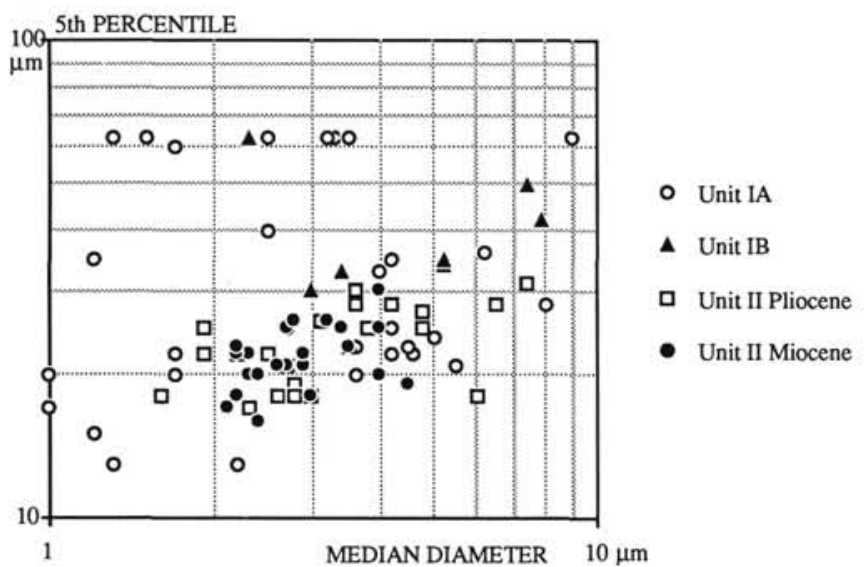

Figure 6. Fifth coarser percentile-median diameter diagram of samples from Site 646.

ited in quiet water. Typical ice-rafting supply is revealed by outsized particles that are scattered in a fine-grained matrix. Thus, we can interpret the changes from silty clays to clayey silts as the result of an increase of the bottom current influence.

Lithological Subunit IB is distinguished by the basal samples, which contain the highest coarse-silt fraction of the entire cored section (Fig. 4). In these clayey silts, the $>63-\mu \mathrm{m}$ fraction is low $(1.3 \%-1.9 \%)$ but significantly higher than in lithologic Unit II and includes granules. This interval contains laminated siliceous silt beds and vaguely color-banded and crudely laminated intervals. No sedimentary structures indicative of turbidites were observed, which may explain the presence of a few coarse particles. These coarse particles confirm that the first contribution of ice-rafting occurs at the base of lithologic Unit I, but the grain-size characteristics of the basal samples more likely indicate sediments winnowed of the fine-grained fraction by bottom currents. The first fine-grained sediments with numerous outsized grains that characterize a major contribution of ice-rafted detritus were identified later, at $195 \mathrm{mbsf}$, where the first dropstone (pebble-sized) was described. This took place near the base of lithologic Subunit IA (188 mbsf), defined by the occurrence of detrital carbonate laminated silt beds. These beds show sequences of structure typical of thin bedded turbidites (Cremer, this volume). Because most of the dropstones are composed of mafic rocks, these detrital carbonate turbidites, commonly more fine-grained than the silty contourite beds (Fig. 7), are interpreted as spillover sediments from the Northwest Atlantic Mid-Ocean Channel (Cremer, this volume; His-

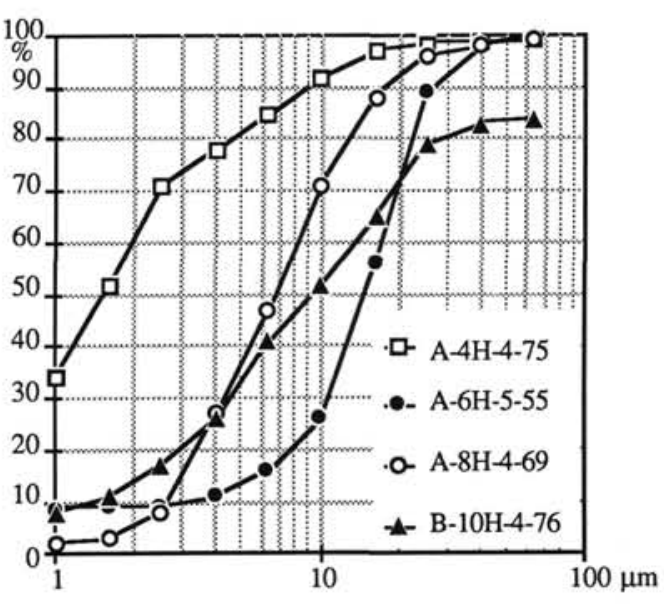

Figure 7. Examples of grain-size distribution for Site 646 of sediments interpreted as (1) pelagite (Sample 105-646A-4H-4, $75 \mathrm{~cm}$ ), (2) contourite (Sample 105-646A-6H-5, $55 \mathrm{~cm}$ ), (3) ice-rafted detritus (Sample 105-646B-10H-4, $76 \mathrm{~cm}$ ), and (4) detrital carbonate turbidite (Sample $105-646 \mathrm{~A}-8 \mathrm{H}-4,69 \mathrm{~cm})$.

cott et al., this volume), which indeed is characterized by the presence of detrital carbonate grains (Latouche and Parra, 1979; Hesse and Chough, 1980). In Subunit IA, the lithologies alternate in a fine-scale cyclicity, which is only partially shown by the studied samples. However, an interval of better sorted clayey silts with a low contribution of outsized grains was distinguished between 100 and $70 \mathrm{mbsf}$, below the lower/upper Pleistocene boundary, and related to an episode of stronger current influence.

The general decrease in mean grain size and the presence in samples of a high coarse-particle content during the late Pleistocene indicate a pronounced weakening of bottom current intensity, the influence of which is only perceptible in a few laminated silt beds, and an important contribution of ice-rafted detritus.

\section{Lithologic Unit II}

Lithologic Unit II may be divided into two subunits, based on the vertical evolution of the median grain diameter (Fig. 2). The boundary is placed at a minimum diameter value observed at $480 \mathrm{mbsf}$ near the Miocene/Pliocene boundary and regional reflector R2 (490 mbsf).

The upper subunit, which includes seismic Unit 2, depicted by a sediment drift shape (Arthur et al., this volume), is charac- 
terized by important fluctuations of the median diameter from sample to sample. The sediments range from clayey silts with symmetrical grain-size curves to less clayey and better sorted silts with distinctly positive skewed grain-size curves (Fig. 5B). Based on these characteristics and their location on the fifth coarser percentile-median diameter diagram (Fig. 6), we interpreted the finer-grained sediments as resulting from decantation in quiet water of uniform fine-grained suspensions, while the coarser-grained sediments have characteristic deposition of graded suspensions under a current influence. The latter first occur at 395 mbsf, where the first laminated siliceous silt layer indicates strong bottom current influence. Except for the laminated silt beds, the sediments are commonly structureless and bioturbated and may contain relatively high biogenic skeletons, as do the contourites described by Chough and Hesse (1985) from the main part of Eirik Ridge and from most of the bottom-current-molded sediment drifts of the North Atlantic (Stow and Holbrook, 1984). Therefore, the changes in grain-size were interpreted as fluctuations of the bottom current. These indicate a slight increase of the current influence at the Miocene/Pliocene boundary, then rapid fluctuations between low and high current intensities above $400 \mathrm{mbsf}$. The samples, however, are too sparse to document the presence of smaller sequences, as indicated by seismic interpretation.

The lower subunit, from the bottom of the hole up to 480 mbsf, may be defined by a fining-upward sequence (Fig. 2). The sediments grade from slightly positive skewed clayey silts to more clayey silts with symmetrical grain-size curves that show a more pronounced hyperbolic shape. In detail, the highest values of mean diameter occur at 720 and 650 mbsf and regularly decrease from $650 \mathrm{mbsf}$. At this depth, the fifth coarser percentile reaches a maximum value similar to those of the upper subunit. These variations occur near the calculated depth of the reflecter R3/R4 doublet (680 and 730 mbsf; Arthur et al., this volume). Although seismic Unit 4 has not been penetrated deeply enough to be characterized with respect to seismic Unit 3, these textural characteristics do indicate current influence at the base of the cored section, with a short interval of a pronounced current influence just above reflector R3, followed by a regular weakening of the current intensity up to the Miocene/Pliocene boundary.

\section{MINERAL COMPOSITION}

\section{Bulk Sediment}

Sedimentation at Site 646 (Fig. 8, Table 1) is carbonate poor. Intervals in which the calcite content is fairly high occur in the upper Miocene between 700 and 540 mbsf; in the lower Pliocene between 450 and 340 mbsf; in the upper Pliocene at about 300 , 240 , and $180 \mathrm{mbsf}$; and throughout the upper Pleistocene, with the calcite content reaching $40 \%$.

Quartz proportions do not vary considerably and range from $4 \%$ to $20 \%$, with a mean value of $15 \%$. Feldspars, of calcosodic nature (3.19-3.17 $\AA$ ), are fairly well represented in the bulk sediment. The following variations were observed: (1) at the base, at 680 mbsf, where feldspar contents are poor, $14 \%$ to $28 \%$; (2) from 680 to about 475 mbsf (early lower Pliocene), where the amounts of feldspar increase, $18 \%-40 \%$; (3) above $475 \mathrm{mbsf}$, feldspars appear in variable proportions, between $8 \%$ and $56 \%$; and (4) at 181,161 , and 87 mbsf feldspars are very abundant.

\section{Clay Minerals and Minerals Associated with $<2-\mu \mathrm{m}$ Fraction}

Clay minerals are represented by chlorites, illites, smectites, and kaolinites. Several interlayered clay minerals occur only in trace amounts. On the basis of the clay assemblage characteristics, two main intervals were disinguished.
From the base of the drilled section to about $680 \mathrm{mbsf}$ (corresponding to seismic reflector R3), the clay assemblage (Fig. 8, Table 1) is mainly composed of smectites $(49 \%$ to $63 \%)$ and some illites, chlorites, and kaolinites. This fine fraction is also associated with scarce amounts of quartz and amphiboles and a few, more abundant, calcosodic feldspars.

From $680 \mathrm{mbsf}$ to the top of the hole, despite a decrease in most levels, smectites continue to be abundant $(21 \%$ to $47 \%)$, while chlorites (13\% to $30 \%)$ and illites $(21 \%$ to $46 \%)$ increase; kaolinites occur less frequently (traces to $18 \%$ ). Quartz is scarce, and calcosodic feldspars are abundant. Amphiboles that occur in more variable proportions are better represented in the lower Pliocene and Pleistocene than elsewhere at Site 646.

The crystallinity index of clay minerals (Table 2), whether illites or smectites, is moderate and varies only slightly. In contrast, the peak resolution of smectites (Table 3) is low below 680 mbsf and variable above this point. Chemical composition of illites seems to vary. From the base to 680 mbsf (reflector R3), they tend to be aluminous $(A<3)$; above $680 \mathrm{mbsf}$, illites are ferriferous $(A>3)$. In certain levels, the illite reflection is so low (002) that one can perform no measurements. Nevertheless, such low peak values confirm the true ferriferous nature of illites at this level. Some rare aluminum-rich illites were observed at $323,282,298$, and 60 mbsf.

\section{DISCUSSION}

\section{Keys of Interpretation}

Interpretation of the mineralogical results was considered in the light of works by several authors, in particular that of Millot (1964), Yeroschev-Shak (1964), Biscaye (1965), Griffin et al. (1968), and Rateev et al. (1969), as well as in light of works about sedimentation in the North Atlantic. Based on all this information, several characteristics were established to serve as keys to the interpretation below.

Bulk sediment minerals, such as quartz, feldspars, and heavy minerals, were used to identify the source rocks and soils from which the sediments could derive as well as to assess the weathering probably responsible for the genesis of these sediments.

For instance, "felsic" rock (e.g., the granite family) may supply, under nonaggressive climatic conditions, large amounts of quartz and feldspars whose chemical composition of the latter mineral may vary from alkaline to calcosodic (Deer et al., 1986; Nockolds et al., 1978). These rocks may also supply ferromagnesian minerals belonging to the amphibole group; the latter are often encountered in periglacial deposits of the North Atlantic (Parra, 1980).

"Basic" rocks (e.g., basalts) supply calcosodic feldspars, practically no quartz, and minerals belonging to the clinopyroxene group, rather than amphiboles (Parra, 1980; Delmont, 1985). Chemical weathering can make unclear the signature of the source rock; this causes degradation of feldspars and an increase in the quartz or resisting minerals to feldspar ratio.

Clay minerals, mainly continentally derived, are good indicators of the climatic conditions prevailing over emerged land (Chamley, 1979). They make it possible to determine the sources of terrigenous materials and, thereby, to establish their provenance as well as differentiate the marine currents responsible for their transport. Smectites, for instance, develop under a warm climate with contrasting seasons (Paquet, 1970). Conversely, less aggressive climatic conditions (cold tendency climate) preserve more labile minerals, such as illites and chlorites (Tardy, 1969). Clay minerals are influenced by the nature of the parent rock. Weathering of basic rocks supplies mostly smectites (YeroschevShak, 1964; Bonatti, 1967; Delmont, 1985), while acid rocks yield illites and chlorites.

To understand the detrital origin of the sediments at Site 646 , we investigated the results of works dealing with the nature 


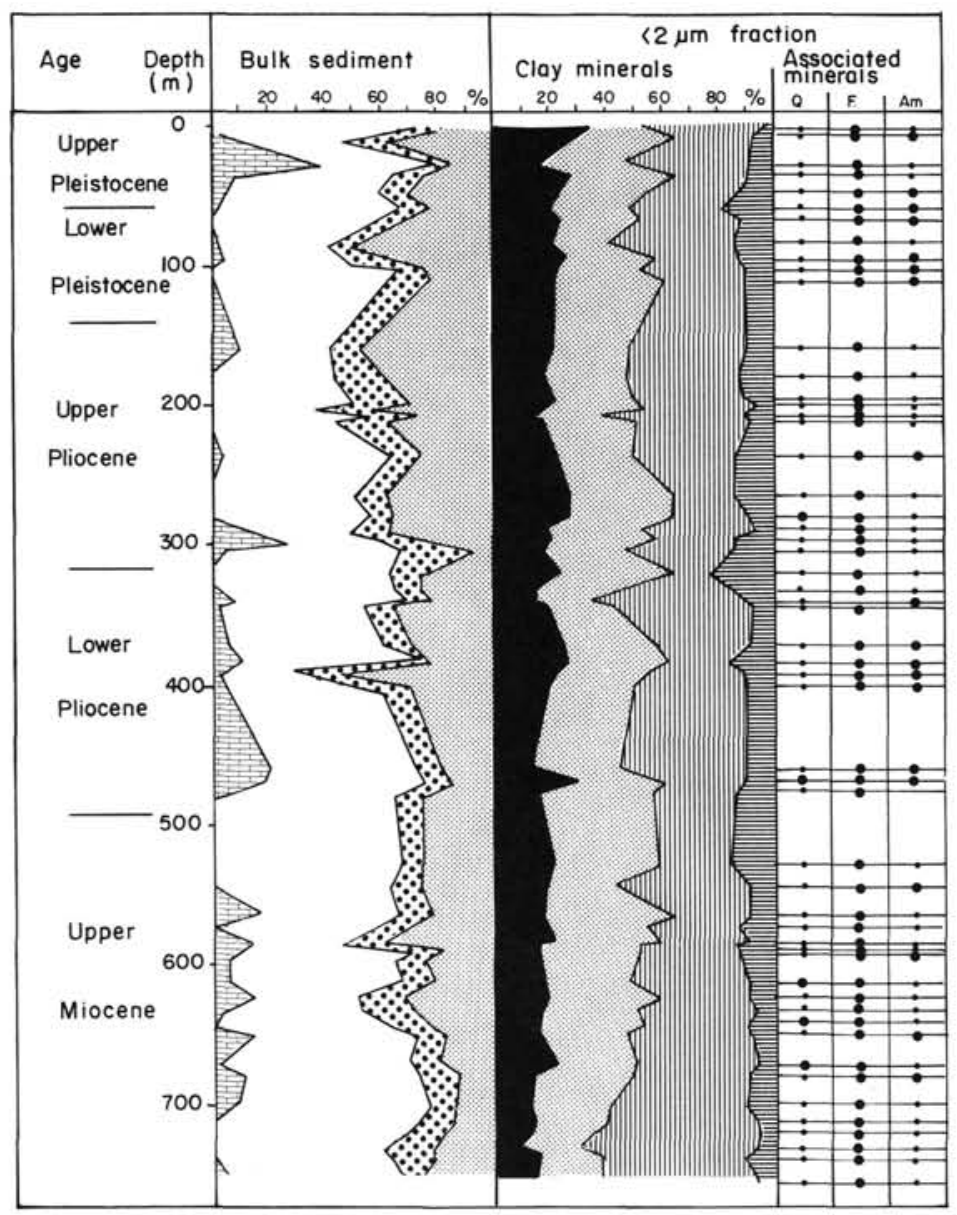

Legend

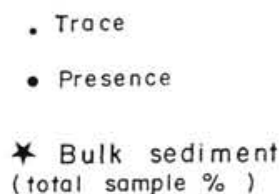

(total sample \%)

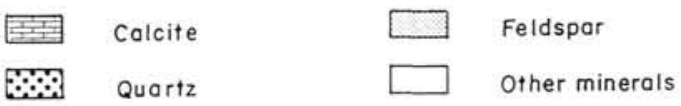

$<2 \mu \mathrm{m}$ fraction

- Clay minerals

( in \% with respect to all

crystallized clay minerals studied)

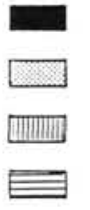

Associated minerals
Q Quartz
F $\quad$ Feldspar
Am Amphibole

Smectite

Kaolinite

Figure 8. Mineralogical log for Site 646.

of rock from neighboring emerged land (Greenland and Iceland) as well as the modern distribution of certain minerals at sea that have a particular petrographic significance (Parra, 1980, Grousset, 1983).

Very old rocks (Precambrian, having undergone metamorphism, from granite and gneiss series) constitute the south Greenland margin out of ice (Lexique Stratigraphique International, 1956; Atlas Géologique du Monde at 1/1,000,000, 1976). According to Berthois (1969) and Berthois et al. (1972), sediments found at the bottom of a fjord on the western coast of Greenland (which is mainly crystallophyllian and where all sorts of rocks compose the ancient basement) are characterized by abundant quantities of feldspars and quartz (calcosodic and alkaline feldspars being more abundant than quartz), micas, ferriferous chlorites, and, occasionally, frequently occurring amphiboles.

Studies of fluvioglacial sediments from these acid rocks (Petersen and Rasmussen, 1980) revealed the existence of some quartz and amphiboles. According to these authors, the sediment also contained a clay phase with well-crystallized vermiculites and smectites, despite the cold climate under which weathering took place.

Basaltic rocks occur on both sides of Greenland beyond the Arctic Circle, in the West, north of the Davis Strait, and in the East around the Denmark Strait. About $80 \%$ of these rocks constitute the Icelandic soil (Grousset, 1983).

Regional modern marine sedimentation is distinctly influenced by the petrographic nature of the surrounding continental domains described above. From Shurko's observations (1966), it appears that quartz is more abundant in Greenland, horn- blendes are concentrated around Greenland and Canada, while minerals such as augite form halos around mainly volcanic regions, as in Iceland.

Studies of marine sediments in the vicinity of Iceland and the Greenland Basin (Parra, 1980; Grousset et al., 1982; Grousset, 1983) indicate a relationship between smectites, clinopyroxenes, and basic volcanic regions. These investigations, therefore, put forward the differences existing between these two large petrographic provinces and emphasize the influence they exert upon neighboring marine sedimentation.

\section{Interpretation}

Mineralogical assemblages of the sediments at Site 646 reveal the existence of a major event at about $680 \mathrm{mbsf}$ and more moderate mineralogical variations from $680 \mathrm{mbsf}$ to the top of the cored section.

\section{Major Mineralogical Event (680 mbsf)}

From the base of the cored section to $680 \mathrm{mbsf}$, the mineralogical assemblage is characterized by abundant smectites. X-ray diagrams (Fig. 9) reveal their importance and good resolution (Table 3); illites are of aluminous type; feldspars of calcosodic type; and quartz is scarce.

Above 680 mbsf to the top of the section, the mineralogical assemblage, despite numerous secondary variations, is marked by the occurrence of large amounts of calcosodic feldspars that continue to be dominant on quartz, and by iron-rich illites and chlorites. Smectites are still well represented and abundant, but 
Table 1. X-ray diffractometry mineralogical results for Site 646 .

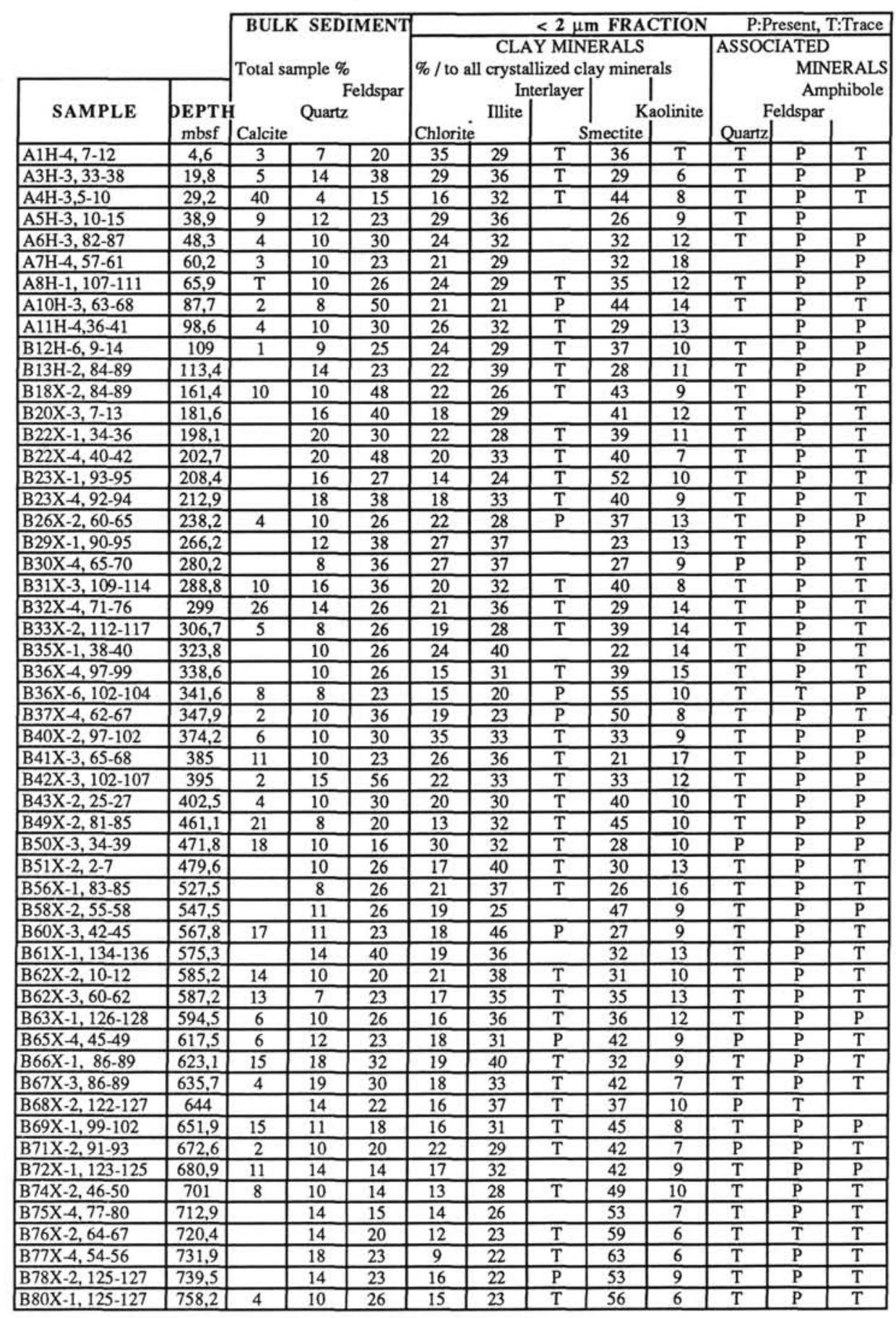

are not as sharp on X-ray diagrams (Fig. 9) as in the previous episode. Amphiboles tend to occur often in the fine fraction.

The occurrence of certain minerals is visible throughout the section: calcosodic feldspars, quartz, illites, chlorites, and amphiboles. This assemblage has all the characteristics commonly attributed to peri-Greenland sediments described above. Thus it appears that the South Greenlandian contribution to sedimentation is constant; it is more important at $680 \mathrm{mbsf}$ and to the top, rather than at the base, of Site 646 . This autochthonous sedimentation also includes a mineral of uncertain origin: smectite. In fact, smectites are particularly abundant below $680 \mathrm{mbsf}$. Several processes can account for its occurrence.
If smectites are considered autochthonous, they may be the result of a warm damp climate with contrasting season over Greenland. While this type of climate is difficult to envisage for the upper Miocene, its persistence in the Pliocene and Pleistocene in these northern latitudes is improbable. On the other hand, smectites may result from eroded ancient formations. Early Tertiary warm climatic (fauna from Western Greenland: Koch, 1963), and even lateritic conditions (Iceland and Faeroe Islands: Nilsen, 1981), must have certainly entailed the development of smectites in these northernmost latitudes. The presence of smectites in the modern fluvioglacial sediments from Greenland was noted by Petersen and Rasmussen in 1980. 
Table 2. Crystallinity index of clay minerals (illites and smectites) for Site 646.

\begin{tabular}{|c|c|c|c|}
\hline Sample & $\begin{array}{l}\text { Depth } \\
\text { mbsf }\end{array}$ & $\begin{array}{l}\text { Crystallin } \\
\text { Illites }\end{array}$ & $\begin{array}{l}\text { y Index of } \\
\text { Smectites }\end{array}$ \\
\hline A1H-4, 7-12 & 4,6 & 4,5 & 0,23 \\
\hline A3H-3, 33-38 & 19,8 & 6,0 & 0,40 \\
\hline $\mathrm{A} 4 \mathrm{H}-3,5-10$ & 29,2 & 4,0 & 0,36 \\
\hline A.5H-3, 10-15 & 38,9 & 4,5 & 0,14 \\
\hline A6H-3, 82-87 & 48,3 & 5,0 & 0,12 \\
\hline A7H-4, 57-61 & 60,2 & 5,0 & 0,16 \\
\hline A $8 \mathrm{H}-1,107-111$ & 65,9 & 6,0 & 0,33 \\
\hline $\mathrm{A} 10 \mathrm{H}-3,63-68$ & 87,7 & 8,0 & 0,16 \\
\hline $\mathrm{A} 11 \mathrm{H}-4,36-41$ & 98,6 & 6,0 & 0,22 \\
\hline B12H-6, 9-14 & 109 & 8,0 & 0,37 \\
\hline B13H-2, 84-89 & 113,4 & 4.5 & 0,20 \\
\hline B18X-2, 84-89 & 161,4 & 4,0 & 0,17 \\
\hline B20X-3, 7-13 & 181,6 & 7,0 & 0,35 \\
\hline B22X-1, 34-36 & 198,1 & 5,0 & 0,42 \\
\hline B22X-4, 40-42 & 202,7 & 6,0 & 0,41 \\
\hline B23X-1, 93-95 & 208,4 & 8,0 & 0,47 \\
\hline B23X-4, 92-94 & 212,9 & 7,0 & 0,30 \\
\hline B26X-2, 60-65 & 238,2 & 6,0 & 0,23 \\
\hline B29X-1, 90-95 & 266,2 & 4,0 & 0,20 \\
\hline B $30 \times-4,65-70$ & 280,2 & 3,5 & 0,16 \\
\hline B31X-3, 109-114 & 288,8 & 6,0 & 0,30 \\
\hline B32X-4, 71-76 & 299 & 5,0 & 0,25 \\
\hline B33X-2, 112-117 & 306,7 & 4,0 & 0,25 \\
\hline B35X-1, 38-40 & 323,8 & 6,0 & 0,33 \\
\hline B36X-4, 97-99 & 338,6 & 5,0 & 0,33 \\
\hline B36X-6, 102-104 & 341,6 & 6,0 & 0,54 \\
\hline B37X-4, 62-67 & 347,9 & 5,0 & 0,53 \\
\hline
\end{tabular}

\begin{tabular}{|c|c|c|c|}
\hline Sample & $\begin{array}{l}\text { Depth } \\
\text { mbsf }\end{array}$ & $\begin{array}{c}\text { Crystall } \\
\text { IIlites }\end{array}$ & $\begin{array}{l}\text { y Index of } \\
\text { Smectites }\end{array}$ \\
\hline B40X-2, 97-102 & 374,2 & 4,0 & 0,37 \\
\hline B41X-3, 65-68 & 385 & 4,0 & 0,41 \\
\hline B42X-3, 102-107 & 395 & 6,0 & 0,16 \\
\hline B43X-2, 25-27 & 402,5 & 4,0 & 0,36 \\
\hline B49X-2, 81-85 & 461,1 & 4,0 & 0,27 \\
\hline B50X-3, 34-39 & 471,8 & 3,5 & 0,12 \\
\hline B51X-2, 2-7 & 479,6 & 5,0 & 0,28 \\
\hline B56X-1, 83-85 & 527,5 & 5,0 & 0,20 \\
\hline B58X-2, 55-58 & 547,5 & 7,0 & 0,45 \\
\hline B60X-3, 42-45 & 567,8 & 4,0 & 0,60 \\
\hline B61X-1, 134-136 & 575,3 & 6,0 & 0,33 \\
\hline B62X-2, 10-12 & 585,2 & 4,0 & 0,33 \\
\hline B62X-3, 60-62 & 587,2 & 4,0 & 0,35 \\
\hline B63X-1, 126-128 & 594,5 & 6,0 & 0,44 \\
\hline B65X-4, 45-49 & 617,5 & 4,0 & 0,38 \\
\hline B66X-1, 86-89 & 623,1 & 4,0 & 0,44 \\
\hline B67X-3, 86-89 & 635,7 & 4,0 & 0,50 \\
\hline B68X-2, 122-127 & 644 & 4,0 & 0,14 \\
\hline B69X-1, 99-102 & 651,9 & 4,0 & 0,52 \\
\hline B71X-2, 91-93 & 672,6 & 6,0 & 0,36 \\
\hline B72X-1, 123-125 & 680,9 & 4,0 & 0,36 \\
\hline B74X-2, 46-50 & 701 & 3,5 & 0,63 \\
\hline B75X-4, 77-80 & 712,9 & 3,5 & 0,54 \\
\hline B76X-2, 64-67 & 720,4 & 5,0 & 0,45 \\
\hline B77X-4, 54-56 & 731,9 & 3,5 & 0,67 \\
\hline B78X-2, 125-127 & 739,5 & 4,0 & 0,57 \\
\hline B80X-1, 125-127 & 758,2 & 5,0 & 0,52 \\
\hline
\end{tabular}

Table 3. The peak-resolution smectite data for Site 646.

\begin{tabular}{|l|c|c|}
\hline \multicolumn{1}{|c|}{ Sample } & $\begin{array}{c}\text { Depth } \\
\text { mbsf }\end{array}$ & $\begin{array}{c}\text { Peak Resolution } \\
\text { of Smectites }\end{array}$ \\
\hline A1H-4,7-12 & 4,6 & 0,68 \\
\hline A3H-3,33-38 & 19,8 & 0,65 \\
\hline A4H-3,5-10 & 29,2 & 0,32 \\
\hline A5H-3, 10-15 & 38,9 & 0,87 \\
\hline A6H-3, 82-87 & 48,3 & 0,57 \\
\hline A7H-4, 57-61 & 60,2 & 0,45 \\
\hline A8H-1, 107-111 & 65,9 & 0,6 \\
\hline A10H-3, 63-68 & 87,7 & 0,75 \\
\hline A11H-4,36-41 & 98,6 & 0,71 \\
\hline B12H-6, 9-14 & 109 & 0,57 \\
\hline B13H-2, 84-89 & 113,4 & 0,49 \\
\hline B18X-2, 84-89 & 161,4 & 0,57 \\
\hline B20X-3, 7-13 & 181,6 & 0,37 \\
\hline B22X-1,34-36 & 198,1 & 0,33 \\
\hline B22X-4,40-42 & 202,7 & 0,44 \\
\hline B23X-1,93-95 & 208,4 & 0,34 \\
\hline B23X-4, 92-94 & 212,9 & 0,4 \\
\hline B26X-2, 60-65 & 238,2 & 0,46 \\
\hline B29X-1,90-95 & 266,2 & 0,67 \\
\hline B30X-4, 65-70 & 280,2 & 0,9 \\
\hline B31X-3, 109-114 & 288,8 & 0,38 \\
\hline B32X-4, 71-76 & 299 & 0,67 \\
\hline B33X-2, 112-117 & 306,7 & 0,49 \\
\hline B35X-1, 38-40 & 323,8 & 0,32 \\
\hline B36X-4,97-99 & 338,6 & 0,48 \\
\hline B36X-6, 102-104 & 341,6 & 0,36 \\
\hline B37X-4, 62-67 & 347,9 & 0,28 \\
\hline
\end{tabular}

\begin{tabular}{|c|c|c|}
\hline Sample & $\begin{array}{l}\text { Depth } \\
\text { mbsf }\end{array}$ & $\begin{array}{c}\text { Peak Resolution } \\
\text { of Smectites }\end{array}$ \\
\hline B40X-2, 97-102 & 374,2 & 0,42 \\
\hline B41X-3, 65-68 & 385 & 0,77 \\
\hline B42X-3, 102-107 & 395 & 1 \\
\hline B $43 X-2,25-27$ & 402,5 & 0,64 \\
\hline B49X-2, 81-85 & 461,1 & 0,4 \\
\hline B50X-3, 34-39 & 471,8 & 0,88 \\
\hline B51X-2, 2-7 & 479,6 & 0,5 \\
\hline B56X-1, 83-85 & 527,5 & 0,94 \\
\hline B58X-2, 55-58 & 547,5 & 0,28 \\
\hline B $60 X-3,42-45$ & 567,8 & 0,6 \\
\hline B61X-1, 134-136 & 575,3 & 0,33 \\
\hline B 62 X-2, 10-12 & 585,2 & 0,32 \\
\hline B62X-3, 60-62 & 587,2 & 0,49 \\
\hline B63X-1, 126-128 & 594,5 & 0,5 \\
\hline B65X-4, 45-49 & 617,5 & 0,45 \\
\hline B66X-1, 86-89 & 623,1 & 0,4 \\
\hline B67X-3, 86-89 & 635,7 & 0,31 \\
\hline B68X-2, 122-127 & 644 & 0,53 \\
\hline B69X-1, 99-102 & 651,9 & 0,31 \\
\hline B71X-2, 91-93 & 672,6 & 0,4 \\
\hline B72X-1, 123-125 & 680,9 & 0,37 \\
\hline B74X-2, 46-50 & 701 & 0,29 \\
\hline B75X $-4,77-80$ & 712,9 & 0,26 \\
\hline B76X-2, 64-67 & 720,4 & 0,25 \\
\hline B $77 X-4,54-56$ & 731,9 & 0,2 \\
\hline B78X-2, 125-127 & 739,5 & 0,19 \\
\hline B80X-1, 125-127 & 758,2 & 0,26 \\
\hline
\end{tabular}

If, on the contrary, smectites are thought to be allochthonous, they may be derived from basaltic zones, where their preferential weathering into smectites (regardless of climate) is a well-established phenomenon (Grim and Güven, 1978; Delmont, 1985). Here, smectites might represent the contribution of North Greenland and Iceland to sedimentation. Or they may be derived from southern latitudes, where the probable existence of a warm climate with contrasting seasons could account for the maximum occurrence of smectites below 680 mbsf. This is in agreement with the faunal results obtained (Aksu and Kaminski, this volume). A change in the foraminiferal faunas is clear at about $680 \mathrm{mbsf}$; it may be attributed to a change in the nature of deep water masses: presence of "AABW" water masses below $680 \mathrm{mbsf}$ and northern water masses above $680 \mathrm{mbsf}$. Given these observations, all observed differences might result from hydrological rather than significant local climatic changes. 


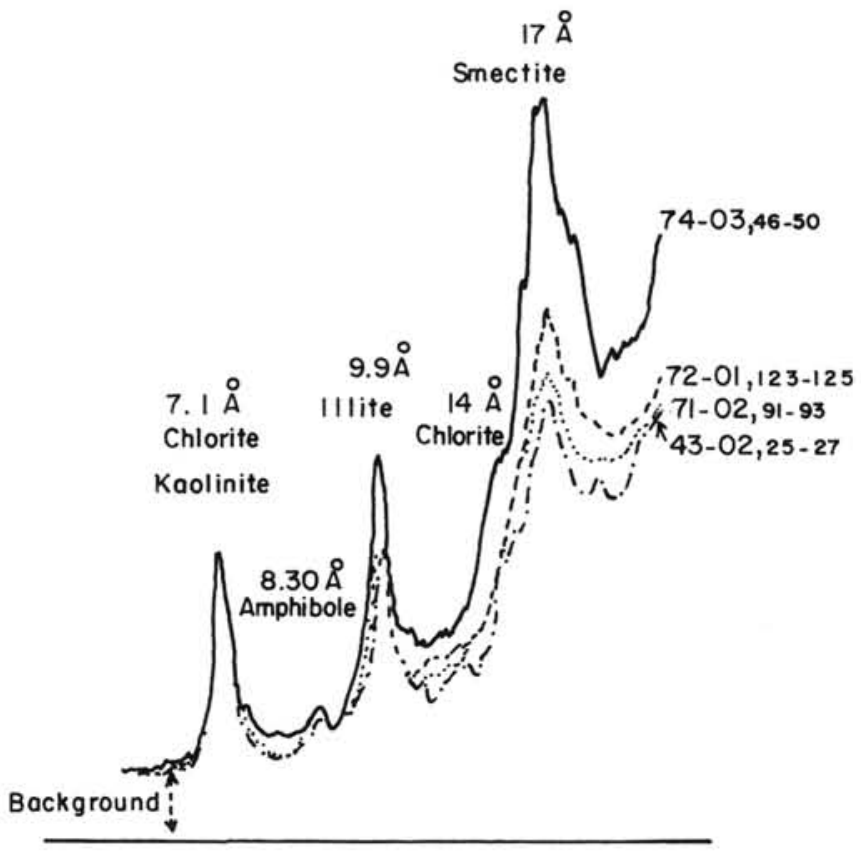

Figure 9. An example of X-ray diagrams.

\section{Mineralogical Fluctuations (680 mbsf to the top)}

The mineralogical fluctuations observed in this interval can be considered in the light of the deposition modes that were distinguished from grain-size analyses. For instance, in lithologic Subunit IA the sediments interpreted as silty contourites are particularly rich in feldspars and smectites (Fig. 10). Conversely, the sediments derived from fine-grained hemipelagite suspensions include higher amounts of quartz and illites. These amounts are highest in the sediments containing coarse ice-rafted particles. Considering the characteristics of supply sources discussed earlier, the presence of abundant feldspars and smectites in the contourite facies suggests an important contribution of basic material (Northern Greenland and/or Iceland area). Therefore, the contour-following bottom currents at Site 646 are consistent with derivation associated with the sinking of NSOW. In contrast, ice-rafted materials show mineral composition (abundant quartz and illites) inherited from felsic rocks and are interpreted as being derived directly from South Greenland. Then, the mineralogical variations from $680 \mathrm{mbsf}$ to top of the hole may be interpreted in terms of hydrological changes leading to variations between local and allocthonous dominant sedimentary influxes.

From 680 to 490 mbsf (seismic reflectors R3 to R2), quartz, illite, and chlorite contents, as well as reduced feldspar and smectite amounts, indicate a dominant felsic source rock and thus local sedimentary influxes from South Greenland.

The interval just above reflector R3, which is characterized by a slight current activity (higher coarse silt content), is not marked by allochthonous influxes (smectites), but rather by a "pulsation" of quartz, illite, and chlorite contents. This might account for the setting of contour bottom currents at a time the NSOW impact had not yet been perceived at this site. However, up to 490 mbsf, the mean grain-size of the sediments as well as the decreased smectite-to-illite ratio agree with a weakening of the bottom current influence and an evolution toward more local sedimentation.

From 490 mbsf to the base of lithologic Unit I ( $238 \mathrm{mbsf}$ ), rapid and occasionally significant variations in smectites, illites, and chlorites indicate changes in the origin of influxes that may be local or may be connected to NSOW. These variations are
SMECTITE / ILLITE

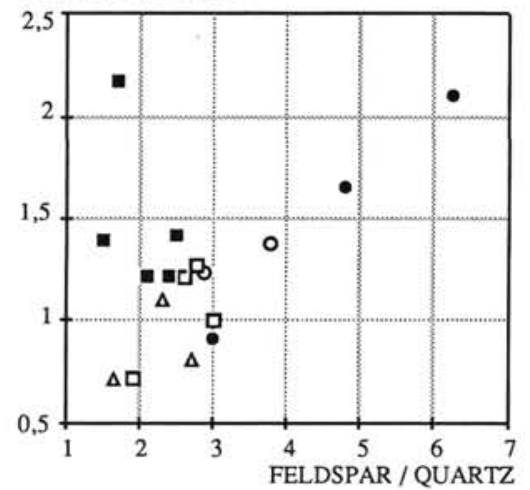

Figure 10. Smectite/illite vs. feldspar/quartz diagram showing mineralogical variations within lithologic Subunit IA from typical silt contourites (closed circles) to hemipelagites, including an increasing amount of ice-rafted material (open circles, open squares, triangles), and distinguishing lithologic Subunit IA (closed squares).

also marked by important changes in the mean grain-size that are related to fluctuations of bottom currents. Mineralogical changes that occurred between the time "basic" influxes attain a maximum toward the base of the Pliocene ( 460 to $400 \mathrm{mbsf}$ ) and a time local "felsic" contribution is at its highest (280 to 265 mbsf). The occurrence of basic rock influxes is interpreted as the first well-marked influence of the NSOW, while that of acid influxes is least affected by NSOW. These changes could indicate the first climatic oscillations leading to general cooling before the onset of major glacial ice-rafting, which was seen at the base of lithologic Unit I.

In lithologic Subunit IB (Fig. 10), high quartz percentages (local influx) are associated with high smectite contents (allochthonous influx). This association supports the interpretation of the particular grain-size characteristics of this subunit as indicative of contour current having, in part, reworked ice-rafted material.

In lithologic Subunit IA, the mineralogical distinction becomes clearer between decantation deposits containing glacial outputs of local character and bottom current-controlled deposits of allochthonous nature.

In summary, our interpretation of the textural and mineralogical variations along the cored section, although they are relatively small, shows that bottom currents have controlled the sedimentation since the beginning of the Pliocene and that these currents were still influential up to the early Pleistocene, despite the onset of ice rafting at about $2.5 \mathrm{Ma}$. The variations between local (felsic source rocks) and allochthonous (basic source rocks) sedimentary influxes generally agree with grain-size data and are related to changes in the intensity of the contour-following bottom currents coming from NSOW. Although no seismic evidence exists for bottom-controlled sedimentation during the late Miocene, grain-size characteristics from the bottom part of the hole suggest an earlier period of pronounced bottom current influence. Moreover, a major mineralogical change, which occured in late Miocene at about $680 \mathrm{mbsf}$, can be related to an important hydrological change that is consistent with a shortterm decrease in sedimentation rate at that depth, deduced from magnetostratigraphy and the change in foraminiferal faunas.

\section{REFERENCES}

Atlas Géologique du Monde au 1/10,000,000 ème, 1976: Paris (UNESCO).

Berthois, L., 1969. Contribution à l'étude sédimentoligique du Kangerdlugssuag, côte ouest du Groenland 1957-1960 (Vol. 7): Meddleser (E.G.I.G.). 
Berthois, L., Latouche, C., and Parra, M., 1972. Contribution à la connaissance des caractères minéralogiques et géochimiques des sédiments du Kangerdlugssuaq (côte ouest du Groenland). Bull. Inst. Géol. Bassin d'Aquitaine (Bordeaux), 12:123-140.

Biscaye, P. E., 1965. Mineralogy and sedimentation of Recent deep-sea clay in the Atlantic Ocean and adjacent seas and oceans. Geol. Soc. Am. Bull., 76:803-832.

Bonatti, E., 1967. Mechanisms of deep-sea volcanism in the South Pacific. Res. Geochem., 2:453-491.

Brindley, G. W., and Brown, G., 1980. Crystal Structures of Clay Minerals and Their $X$-ray Identification (Vol. 5): London (Mineralogical Society).

Brown, G., 1961. The X-ray Identification and Crystal Structures of Clay Minerals: London (Mineralogical Society).

Chamley, H., 1979. North Atlantic clay sedimentation and paleoenvironment since the Late Jurassic. In Talwani, M., Hay, W., and Ryan, W.B.F. (Eds.), Deep-sea Drilling Results in the North Atlantic: Continental Margins and Paleoenvironments: Washington (Am. Geophys. Union ), 342-361.

Chough, S. K., and Hesse, R., 1985. Contourites from Eirik Ridge, south of Greenland. Sediment. Geol., 41:185-199.

Deer, W. A., Howie, R. A., and Zussman, J., 1986. An Introduction to the Rock Forming Minerals: London (Longman), 2nd ed.

Delmont, P., 1985. Smectites et produits d'altération des basaltes tertiaires des Iles Faeroe (Atlantique Nord-Est). Génèse, évolution et contribution à la sédimentation océanique [Thèse de 3ème Cycle en Océanologie]. Université de Bordeaux I.

Dunoyer de Segonzac, G., 1969. Les minéraux argileux dans la diagénèse. Passage au métomorphisme. Mem. Serv. Carte Géol. AlsaceLorraine, 29.

Esquevin, J., 1969. Influence de la composition chimique des illites sur la cristallinité. Bull. Centre de Recherche de Pau, 3:147-154.

Friedman, G. M., 1967. Dynamic processes and statistical parameters compared for size frequency distribution of beach and river sands. J. Sediment. Petrol., 37:327-354.

Griffin, J. J., Window, H., and Goldberg, E. D., 1968. The distribution of clay minerals in the world ocean. Deep-Sea Res., 15:433-459.

Grim, R. E., Bradley, W. F., and Brown, G., 1951. The mica clay minerals. In Brindley, G. W. (Ed.), X-ray Identification and Crystal Structure of the Clay Minerals: London (Mineralogical Society), 138-172.

Grim, R. E., and Güven, N., 1978. Bentonites. Geology, Mineralogy, Properties and Uses: Developments in Sedimentology (Vol. 24): Amsterdam (Elsevier).

Grousset, F., Latouche, C., Parra, M., 1982. Late Quaternary sedimentation between the Gibbs Fracture and the Greenland Basin: mineralogy and geochimical data. Mar. Geol., 47:303-330.

Grousset, F., 1983. Sédimentogénèse d'un environement de dorsale: la ride Açores-Islande au cours du dernier cycle climatique. Origines, vecteurs, flux des particules sédimentaires (Thése de Doctorat d'état). Université de Bordeaux I.

Hesse, R., and Chough, S. K., 1980. The Northwestern Atlantic MidOcean Channel of the Labrador Sea: II, deposition of parallel laminated levee-muds from the viscous sublayer of low density turbidity currents. Sedimentology, 27:697-711.

Jones, E.J.W., Ewing, M., Ewing, J. I., and Eittreim, S. L., 1970. Influences of Norwegian Sea overflow water on sedimentation in the northern North Atlantic and Labrador Sea. J. Geophys. Res., 75: $1655-1680$.

Klingebiel, A., and Latouche, C., 1962. Etude cristallographique des illites dans les séries eocènes du Bordelais. C. R. Acad. Soc. Paris, 255:142-144.
Koch, B .E., 1963. Fossil plants from lower Paleocene of the Agatdalen (Angmartussut) area, central Nugssuag Peninsula, North West Greenland. Medd. Groenl., 172.

Latouche, C. and Parra, M., 1979. La sedimentation au Quaternaire récent dans le "Northwest Atlantic Mid-Ocean Canyon," apport des données minéralogiques et géochimiques. Mar. Geol., 29:137-164.

Lexique Stratigraphique International, 1956. Congrés Géologique International, Commission de Statigraphie: Paris (Edition du CNRS).

Millot, G., 1964. Géologie des argiles: Paris (Masson).

Nilsen, H., 1981. Influence of the Scotland ridge on the geological history of the North Atlantic and Norwegian-Greenland sea areas. In Bott, H. P., et al. (Eds.), Structure and Development of the Greenland-Scotland Ridge: New Methods and Concepts: London (Plenum Press), 457-478.

Nockolds, S. R., Knox, R. W. O’B, and Chinner, G. A., 1978. Petrology for Students: Cambridge (Cambridge University Press).

Paquet, H., 1970. Evolution géochimique des minéraux argileux dans les altérations et les sols des climats méditérranéens et tropicaux à saisons contrastées. Mém. Serv. Carte Géol. Alsace-Lorraine, 30.

Parra, M., 1980. Apports des données minéralogiques et géochimiques à la connaissance de la sédimentation profonde et de l'hydrologie de l'Océan Nord Atlantique pendant le Quaternaire terminal (dernier glaciaire et Postglaciaire) [Thése de Doctorat d'état]. Université de Bordeaux I.

Passega, R., 1957. Texture as characteristic of clastic deposition. AAPG Bull., 41:1952-1974.

Petersen, L., and Rasmussen, K., 1980. Mineralogical composition of the clay fraction of the two fluvio-glacial sediments from East Greenland. Clay Minerals, 15:135-145.

Rateev, M. A., Gorbunova, Z. N., Lisitzyn, A. P., and Nosov, G. L., 1969. The distribution of clay minerals in the ocerns. Sedimentology, 13:21-43.

Rivière, A., 1977. Méthodes Granulométriques: Techniques et Interprétation: Paris (Masson).

Shipboard Scientific Party, 1987. Site 646. In Srivastava, S. P., Arthur, M., et al., Proc. ODP, Init. Repts., 105: College Station, TX (Ocean Drilling Program), 419-674.

Shurko, I. I., 1966. Terrigenous-volcanic minerals in modern sediments of the North Atlantic. Doklady Akad. Nauk SSSR, 171:461-464.

Stow, D.A.V., and Holbrook, J. A., 1984. North Atlantic contourites: an overview. In Stow D.A.V., and Piper, D.J.W. (Eds.), Fine-Grained Sediments: Deep Water Processes and Facies. Geol. Soc. London Spec. Publ., 15:245-256.

Tardy, J., 1969. Géochimie des altérations. Etude des arènes et des eaux de quelques massifs cristallins d'Europe et d'Afrique. Mém. Serv. Carte Géol. Alsace-Lorraine, 31.

Thorez, J., 1975. Phyllosilicates and Clay Minerals: A Laboratory Handbook for their X-ray Diffraction Analysis: Dison (Lelotte).

Torre de Assunçao, C., and Garrido, J., 1953. Tables pour la Détermination des Minéraux au Moyen des Rayons X. Bull. Musée et Laboratoire Minéralogique et Géochimique de la faculté des Sciences de Lisbonne.

Yeroschev-Shak, V. A., 1964. Clay minerals of the Atlantic Ocean. Soviet Oceanogr., 30:90-106.

Date of initial receipt: 6 July 1987

Date of acceptance: 24 May 1988

Ms B105-114 